\title{
Retardation of Rutab Development of "Zaghloul" Dates and Enhancing Bunch Ripening Uniformity by Preharvest Application of Calcium and the Antiethylene Compound 1- Amino Cyclopropene, 1- Mcp. Farag, K. M. ${ }^{1}$; Neven M. N. Nagy ${ }^{1}$ and Safaa M. Elnoam ${ }^{2}$. ${ }^{1}$ Department of Horticulture (Pomology), Faculty of Agriculture, Damanhour University, P.O.Box 22516, Damanhour, Egypt. \\ ${ }^{2}$ Horticulture Research Institute, Egypt.
}

\section{ABSTRACT}

Consumption of "Zaghloul" date fruits is highly demanded especially at the bisr stage. Date growers complain about the nonuniformity of the bunch that leads to greater loss of fruits either due to increase abscission prior harvest or deterioration of dates at the rutab stage. This study utilized the antiethlyene-action compound, namely 1-Methylcyclopropene along with calcium near maturity to inhibit the ripening (rutab development) of the dates that already have reached to the bisr stage, while the dates that were still near the end of the kimri stage continued to grow. Dates were preharvest sprayed during the two consecutive seasons 2015 and 2016 to the run off by using a hand sprayer. The treatments included the control (water), 1- MCP at (50 ppm) known as Smart Fresh,

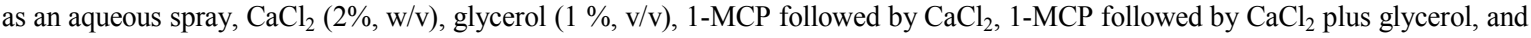
finally $\mathrm{CaCl}_{2}$ plus glycerol at the same above concentrations. The whole bunches of all replications were harvested and sorted for their content of various ripening stages, namely bisr, semi- dry and rutab. The data revealed that almost all fruits were at the bisr stage at harvest time during the two seasons when they were treated first with 1 - MCP followed by $\mathrm{CaCl}_{2}$ plus glycerol, while the control bunches had significantly lower percentage of bisr dates as compared with the above treatments. Meanwhile, dates treated with 1- $\mathrm{MCP}$ followed by $\mathrm{CaCl}_{2}$ plus glycerol had significantly greater anthocyanin content at harvest than that of the control in both seasons. Furthermore, all 1- MCP- treated fruits had significantly lower leakage of electrolytes than that of the control dates. In conclusion, this study provided a practical evidence for the possibility of utilizing $1-\mathrm{MCP}$ as a mean of enhancing uniformity and delaying the progress towards the ripening of "Zaghloul" dates and extending the bisr stage.

\section{INTRODUCTION}

Date palm is one of the most important fruit crops in the world. The fruit has been described as a wealth of healthy components (Farag, 2016), since the fruit is loaded with sugars, nutrients and antioxidants. In spite of the rank of Egypt worldwide in the production of dates as the second country following Iran (Zaid and DeWet, 1999), there is still a great potential to increase the yield, enhance the quality and reduce the losses whether pre or postharvest. Major part of the loss could be attributed to the nonuniformity of date fruits within the same bunch. Dates advanced in their growth and development and ripening are subjected to abscission, since some fruits inside the bunch might reach to the rutab stage before the others. Eventhough rutab stage is accompanied by softening, it has been considered as the ripening stage.

Many date fruits fall off the bunch once reached to ripening stage. Since date fruit growth curve is sigmoidal, the fruits may vary in their development stage by the end of the cell elongation stage known as Kimri stage. Thus, it is important to retard the progress towards ripening or entering the rutab phase.

There has been a lack of research attempts to achieve fruit ripening uniformity within the same bunch. Few attempts focused only on preharvest spray of ethephon, the ethylene - releasing compound, in order to enhance fruit ripening (Farag and Kassem, 1998). The variations in dates growth and development greatly influence the response and the efficacy of sprayed chemicals. Fruit tissue variations influence their sensitivity to applied compounds in addition to the need to enhance the penetration of applied ethephon across the fruit cuticle (Farag and Kassem, 1998).

"Zaghloul" date is one of the few cultivars that could be consumed at the bisr stage due to the conversion of soluble tannins to insoluble form, which reduces their astringency. It is important that the fruit is sweet and not bitter (Farag, 2016). There are few date cultivars that are suitable for marketing and consumption at the Khalal stage such as Zaghloul, Samany, Barhi and Khalas. They could have more potential of export to the European and other foreign markets to gain more profits. Thus, the increase in the percentage of Khalal fruits at harvest would mean better marketability and reduced loss.

The use of the antiethylene compound, namely 1methyl cyclo propene (1-MCP) would result in delaying the ripening processes even in the presence of ethylene, since 1-MCP occupies the binding sites inside the fruit tissues, which gives the chance of dates near the end of the Kimri stage to grow and catch up with other fruits at more advanced stage of development.

Calcium, on the other hand, was able to maintain the plasma membrane integrity and to preserve the structure of the cell walls in plant cells (Farag, 2010). Thus, the objectives of this study were to increase the uniformity of "Zaghloul" dates at harvest while maintaining the integrity and reducing the deterioration of tissues and providing the growers with a novel- applicable approach that utilizes 1MCP and calcium.

\section{MATERIALS AND METHODS}

This study was conducted during the two consecutive seasons 2015 and 2016 on "Zaghloul" date palm trees grown in a private orchard at Edko region, Behira governorate, Egypt. Trees were seventeen years old, nearly uniform, healthy, grown in a sandy soil, spaced at $7 \times 7 \mathrm{~m}$ and received common horticulture practices. Four date palm trees were selected for implementing the investigation treatments and each one of these trees was exposed to all treatments (tree as a block). Each three bunches of each chosen tree at the tribal part of each tree were separately sprayed to the run off using a hand sprayer on 28 of August during 2015 and 2016, seasons (at the end of kimiri phase) with one of the following solutions:- Control (water); 1-methylecyclopropene (MCP) at $50 \mathrm{ppm}(\mathrm{v} / \mathrm{v})$; calcium chloride at $2 \%(\mathrm{w} / \mathrm{v})$; glycerol at $1 \%$ $(\mathrm{v} / \mathrm{v}) ; \mathrm{MCP}$ at $50 \mathrm{ppm}$ and after dryness followed by calcium chloride at 2\%; MCP at $50 \mathrm{ppm}$ and after drying out followed by calcium chloride at $2 \%(\mathrm{w} / \mathrm{v})$ plus glycerol at $1 \%(\mathrm{v} / \mathrm{v})$ 
and finally, the combination of calcium chloride plus glycerol at the same mentioned concentrations. Tween- 20, as a surfactant agent with $0.05 \%$, was added to all these solutions.

The treated -"Zaghloul" dates were collected when reached to khalal stage on 29 and 30 of September for the two consecutive seasons of the study. "Zaghloul" dates of each three bunches received the same treatment of each tree were taken to estimate the percentages of bisr, semi -dry and rutab fruits. Subsequently, ten fruits had a similar treatment per each day were used as a replicate for the determination of physical characteristics included fruit number per strand, fruit weight (gm), fruit diameter $(\mathrm{cm})$ using a hand caliper, seed weight (gm), capsule weight (gm), flesh weight (gm), and at the end flesh to seed ratio was also calculated. The chemical characteristics involved anthocyanin content of fruit peel, which was done by the method of Fuleki and Francis (1968), electrolyte conductivity (\%) expressed as a percentage of total leakage using a conductivity meter, the percentage of total sugars was determined according to the method of Egan et al. (1987). Moreover, the percentage of total soluble solids content (TSS) was determined by hand refractometer and the percentage of titratable acidity (gm/100 ml juice) was evaluated according to Egan et al. (1987), subsequently, the ratio between total soluble solid content and titratable acidity was calculated. In addition, vitamin $\mathrm{C}$ as $\mathrm{mg}$ ascorbic acid /100 $\mathrm{ml}$ juice was assessed in accordance with the method of Egan et al. (1987). Finally, calcium and magnesium contents of "Zaghloul" treated and dried palm fruits were determined according to Jackson (1967). While, potassium content of date fruits based on dry weight was evaluated using flame photometer (Jackson, 1967).

Experimental design was laid out as a randomized completely blocks (RCBD). The SAS computer program
(1996) was utilized to acquire ANOVA and LSD (at 0.05 level).

\section{RESULTS}

\section{1-Physical Characteristics}

The effect of various treatments before harvest on "Zaghloul" date fruit physical characteristics during the two consecutive seasons 2015 and 2016 was reported in Table 1. The number of fruit per strand did not significantly vary among all used treatments in both seasons. Meanwhile, the number of fruits per of strand in the control was similar to that obtained with other treatments in a consistent manner in the two seasons.

With regard to fruit weight at harvest, the data in Table 1 indicated that preharvest treatments of compound such as $\mathrm{CaCl} 2$, glycerol or their combination caused a significant increase in fruit weight as compared with the control in both seasons. Meanwhile, all treatments that included MCP resulted in similar fruit weight at harvest and had superior fruit weight to that obtained with the control. However, fruit weight values with 1 - MCP alone was smaller than those found when 1 - MCP was followed by $\mathrm{CaCl} 2$ or by $\mathrm{CaCl} 2$ plus glycerol. That was not exactly the trend when fruit diameter was analyzed at harvest, since the largest fruit diameter was found with preharvest application of 1 - MCP followed by the spray of $\mathrm{CaCl} 2$ plus glycerol. Moreover, when 1 - MCP application was followed with $\mathrm{CaCl} 2$, they both had similar fruit diameter. However, the application of $\mathrm{CaCl} 2$ plus glycerol resulted in a similar fruit diameter to that obtained with MCP followed by $\mathrm{CaCl} 2$ alone during the two seasons. In addition, the lowest fruit diameter was found with the control or 1 - MCP.

Table 1. Effect of preharvest treatments with safe chemicals on some physical characteristics of "Zaghloul" date palm fruits during 2015 and 2016.

\begin{tabular}{|c|c|c|c|c|c|c|c|c|c|c|}
\hline \multirow{2}{*}{$\begin{array}{l}\text { Characteristics } \\
\text { Treatments }\end{array}$} & \multicolumn{2}{|c|}{$\begin{array}{c}\text { Fruit number } \\
\text { /Strand }\end{array}$} & \multicolumn{2}{|c|}{$\begin{array}{c}\text { Fruit weight } \\
\text { (gm) }\end{array}$} & \multicolumn{2}{|c|}{$\begin{array}{c}\text { Fruit diameter } \\
(\mathrm{cm})\end{array}$} & \multicolumn{2}{|c|}{$\begin{array}{l}\text { Seed weight } \\
\text { (gm ) }\end{array}$} & \multicolumn{2}{|c|}{$\begin{array}{c}\text { Capsule weight } \\
\text { (gm ) }\end{array}$} \\
\hline & 2015 & 2016 & 2015 & 2016 & 2015 & 2016 & 2015 & 2016 & 2015 & 2016 \\
\hline & $8.25 \mathrm{~ns}$ & $9.50 \mathrm{~ns}$ & & & & & $2.21 \mathrm{~ns}$ & $2.35 \mathrm{~ns}$ & & $7 \mathrm{~b}$ \\
\hline & & & & & & & 2.19 & & & \\
\hline & 8. & & $a b$ & 26. & 2.6 & & 2.17 & & & \\
\hline & & & & & & & & & & \\
\hline MC & 9.00 & 9.00 & $\mathrm{ab}$ & & 2. & & 2.15 & $2 .$. & & \\
\hline 1 h $\mathrm{CoCl}$ & 8.75 & 9.25 & $27.58 \mathrm{a}$ & $28.75 \mathrm{a}$ & $2.71 \mathrm{a}$ & $2.83 \mathrm{a}$ & 2.32 & 2.51 & $0.18 \mathrm{~b}$ & $0.25 \mathrm{~b}$ \\
\hline $\mathrm{CaCl}_{2} \mathrm{p}$ & 8.50 & 9.25 & $26.45 \mathrm{ab}$ & $26.59 \mathrm{ab}$ & $2.64 b c$ & $2.72 b c$ & 2.15 & 2.38 & $0.20 \mathrm{~b}$ & $0.26 \mathrm{~b}$ \\
\hline
\end{tabular}

Ns: Non-significant.

*: Means having the same letter (s) within the column are not significantly different when compared according to the least significant difference (LSD at 0.05 level).

The influence of various used treatments on seed weight at harvest proved that all treatments and the control had similar seed weight in a consistent manner in both seasons (Table 1). However, a slight difference was obtained with capsule weight since that property was significantly greater with the glycerol application as compared with other treatments while the smallest capsule was found with 1 - MCP followed by $\mathrm{CaCl} 2$. Moreover, capsule weight of the control was similar to that obtained with either $\mathrm{CaCl} 2, \mathrm{MCP}$ alone, or MCP that was followed with $\mathrm{CaCl} 2$ alone or $\mathrm{CaCl} 2$ plus glycerol (Table 1).

In Table 2, more results were shown for some physical characteristics of "Zaghloul" dates at harvest in response to preharvest treatments. The data revealed that flesh weight was increased by various used treatments as compared with the control in both seasons. However, the greatest increase in flesh weight was obtained when MCP was applied prior to the application of $\mathrm{CaCl}_{2}$ plus glycerol but did not significantly vary from some other treatments such as $\mathrm{MCP}$ followed by $\mathrm{CaCl}_{2}, \mathrm{CaCl}_{2}$ plus glycerol, glycerol alone, and $\mathrm{CaCl}_{2}$ in the first season.

The response of the flesh to seed ratio to various applied treatments was also reported in Table 2. The data showed a significant increase in flesh to seed ratio in the first season, such ratio was only increased by the application of $\mathrm{MCP}$ when followed by $\mathrm{CaCl}_{2}$ or $\mathrm{CaCl}_{2}$ plus glycerol and finally by the application of $\mathrm{CaCl}_{2}$ plus glycerol. 
Table 2. Effect of preharvest treatments with safe chemicals on some physical characteristics of "Zaghloul" date palm fruits during 2015 and 2016.

\begin{tabular}{|c|c|c|c|c|}
\hline Characteristics & \multicolumn{2}{|c|}{ Flesh weight (gm) } & \multicolumn{2}{|c|}{ Flesh: Seed (ratio) } \\
\hline Treatments & 2015 & 2016 & 2015 & 2016 \\
\hline Control & $18.47 \mathrm{c}^{*}$ & $18.86 \mathrm{c}$ & $8.38 \mathrm{~b}$ & $8.05 \mathrm{c}$ \\
\hline $\operatorname{MCP}(50 \mathrm{ppm})$ & $22.58 \mathrm{~b}$ & $22.25 \mathrm{~b}$ & $10.30 \mathrm{a}$ & $8.91 \mathrm{bc}$ \\
\hline $\mathrm{CaCl}_{2}(2 \%)$ & $23.49 \mathrm{ab}$ & $23.25 \mathrm{~b}$ & $10.83 \mathrm{a}$ & $9.17 \mathrm{abc}$ \\
\hline Glycerol (1\%) & $23.79 \mathrm{ab}$ & $23.81 \mathrm{ab}$ & $10.35 \mathrm{a}$ & $9.11 \mathrm{abc}$ \\
\hline MCP followed by $\mathrm{CaCl}_{2}$ & $24.09 \mathrm{ab}$ & $24.08 \mathrm{ab}$ & $11.22 \mathrm{a}$ & $9.57 \mathrm{ab}$ \\
\hline MCP followed by $\mathrm{CaCl}_{2}$ plus glycerol & $25.08 \mathrm{a}$ & $25.97 \mathrm{a}$ & $10.80 \mathrm{a}$ & $10.37 \mathrm{a}$ \\
\hline $\mathrm{CaCl}_{2}$ plus glycerol & $24.11 \mathrm{ab}$ & $23.94 \mathrm{ab}$ & $11.24 \mathrm{a}$ & $10.06 \mathrm{ab}$ \\
\hline
\end{tabular}

*: Means having the same letter (s) within the colum are not significantly different when compared according to the least significant difference (LSD at 0.05 level).

\section{2- Retardation of Rutab Development and Enhancing} Bunch Fruit Uniformity

The data in Table 3 showed the percentages of each type of date fruits based on their maturity (Bisr stage) or ripening uniformity (Semi - dry and Rutab dates) as influenced by preharvest applications of the anti - ethylene compound named $1-\mathrm{MCP}$ or $\mathrm{CaCl}_{2}$. The data revealed that almost all fruits were at the Bisr stage at harvest time (98.20 and $98.97 \%$ ) for the two seasons respectively when they were treated first with 1 -MCP followed by $\mathrm{CaCl}_{2}$ plus glycerol, while the control had 70.00 and $72.46 \%$ for the two seasons, respectively. Meanwhile, great uniformity of fruits was obtained by the application of 1- MCP followed by $\mathrm{CaCl}_{2}$, which was similar to the obtained percentages of Bisr dates at harvest by 1 -MCP treatment only in both seasons (Table 3).

Table 3. Effect of preharvest treatments with safe chemicals on the percentages of ripening stages as an indicator to the bunch uniformity of "Zaghloul" date palm fruits during 2015 and 2016.

\begin{tabular}{|c|c|c|c|c|c|c|}
\hline \multirow[b]{2}{*}{ Treatments } & \multicolumn{2}{|c|}{ Bisr fruits (\%) } & \multicolumn{2}{|c|}{ Semi-dry fruits $(\%)$} & \multicolumn{2}{|c|}{ Rutab fruits (\%) } \\
\hline & 2015 & 2016 & 2015 & 2016 & 2015 & 2016 \\
\hline Control & $70.00 \mathrm{e}^{*}$ & $72.46 \mathrm{e}$ & $19.23 \mathrm{a}$ & $16.15 \mathrm{a}$ & $10.77 \mathrm{a}$ & $11.39 \mathrm{a}$ \\
\hline MCP (50ppm) & $90.23 \mathrm{~b}$ & $91.80 \mathrm{~b}$ & $7.85 \mathrm{e}^{4}$ & $6.20 \mathrm{e}$ & $1.92 \mathrm{e}$ & $2.00 \mathrm{e}$ \\
\hline $\mathrm{CaCl}_{2}(2 \%)$ & $80.36 \mathrm{c}$ & $81.50 \mathrm{~cd}$ & $13.82 \mathrm{c}$ & $12.25 \mathrm{c}$ & $5.82 \mathrm{c}$ & $6.25 \mathrm{c}$ \\
\hline Glycerol $(1 \%)$ & $75.17 \mathrm{~d}$ & $77.25 \mathrm{de}$ & $17.42 \mathrm{~b}$ & $15.00 \mathrm{~b}$ & $7.41 \mathrm{~b}$ & $7.75 \mathrm{~b}$ \\
\hline MCP followed by $\mathrm{CaCl}_{2}$ & $94.31 \mathrm{ab}$ & $95.45 \mathrm{ab}$ & $4.64 \mathrm{f}$ & $3.28 \mathrm{f}$ & $1.05 \mathrm{f}$ & $1.27 \mathrm{f}$ \\
\hline $\mathrm{MCP}$ followed by $\mathrm{CaCl}_{2}$ plus glycerol & $98.20 \mathrm{a}$ & $98.97 \mathrm{a}$ & $1.80 \mathrm{~g}$ & $1.03 \mathrm{~g}$ & $0.00 \mathrm{~g}$ & $0.00 \mathrm{~g}$ \\
\hline $\mathrm{CaCl}_{2}$ plus glycerol & $83.13 \mathrm{c}$ & $85.36 \mathrm{c}$ & $12.67^{\circ} \mathrm{d}$ & $9.32 \mathrm{~d}$ & $4.20 \mathrm{~d}$ & $5.32 \mathrm{~d}$ \\
\hline
\end{tabular}

*: Means having the same letter (s) within the colum are not significantly different when compared according to the least significant difference (LSD at 0.05 level).

\section{3- Chemical Characteristics}

The effect of preharvest treatments with some safe chemicals in addition to the antiethylene compound called 1MCP on the percentage of electrolyte leakage from date tissues was reported in Table 4. The greatest leakage percentage among all treatments was found with the control, while the least electrolyte leakage was obtained with the application of 1 - MCP followed by $\mathrm{CaCl}_{2}$ plus glycerol as well as 1 - MCP followed by $\mathrm{CaCl}_{2}$ alone. The application of 1 -MCP was also capable of significantly reducing electrolyte leakage compared to the control or the two other treatments using 1 - MCP first prior to the application of either $\mathrm{CaCl}_{2}$ alone or plus glycerol. Even when $\mathrm{CaCl}_{2}$ was combined with glycerol, it resulted in lower electrolyte leakage than the application of $\mathrm{CaCl}_{2}$ or glycerol alone. Aforementioned, all applied treatments were effective in reducing electrolyte leakage from fruit tissue when compared with the control but the efficacy varied significantly among all such treatments.

Concerning the changes in anthocyanin content in the date skins, as influenced by various applied treatments, the data showed that the greatest increase in anthocyanin was obtained when MCP was first applied then followed with $\mathrm{CaCl}_{2}$ which was also similar to that found with glycerol
In addition, the application of $\mathrm{CaCl}_{2}$ plus glycerol was able to cause a significant increase in the percentage of Bisr dates at harvest when compared with the control. Furthermore, the least percentages of the Semi - dry or Semi - rutab dates at harvest were found with the application of 1 - $\mathrm{MCP}$ followed $\mathrm{CaCl}_{2}$ plus glycerol then the application of 1 - MCP followed by $\mathrm{CaCl}_{2}$ alone. It was also evident that the individual application of 1 - MCP resulted in significantly lower percentage of Semi - dry dates than that dates bunches treated with $\mathrm{CaCl}_{2}$ alone and the control bunches. On the other hand, the percentage of rutab dates in each bunch was significantly lower in all treatments that included 1 - MCP whether alone or when followed by either $\mathrm{CaCl}_{2}$ plus glycerol or with just $\mathrm{CaCl}_{2}$ in a consistent manner in both seasons. Meanwhile, the greatest percentage of rutab fruits was found in the control bunches (10.77 and $11.39 \%)$ during the two seasons, respectively (Table 3 ). alone. Moreover, dates treated with either $\mathrm{CaCl}_{2}(2 \%)$ or 1 $\mathrm{MCP}$ had a significant increase in anthocyanin relative to the control (Table 4). Meanwhile, two more treatments were equally effective in increasing anthocyanin in the date fruit skins which were 1 - MCP followed by $\mathrm{CaCl}_{2}$ plus glycerol and $\mathrm{CaCl}_{2}$ plus glycerol in the absence of $1-\mathrm{MCP}$ in a consistent manner in both seasons. Thus, all treatments were able to increase anthocyanin content with varying effectiveness when compared with the control.

Concerning the response of total sugars to preharvest applied treatments, the data in Table 4 indicated to a significant increase in such sugars by all used treatments as compared with the control in a consistent trend in both seasons. However, the greatest increase in total sugars was obtained with the application of either glycerol or $\mathrm{CaCl}_{2}$. Moreover, the application of $\mathrm{CaCl}_{2}$ plus glycerol whether alone or following 1-MCP were equally effective in increasing total sugars in "Zaghloul" date fruits. Moreover, treatment that included 1 - MCP when followed by $\mathrm{CaCl}_{2}$ alone or $\mathrm{CaCl}_{2}$ plus glycerol had similar influence on the total sugars of "Zaghloul" dates in both seasons at harvest, while did not vary from using 1 -MCP in a consistent manner.

Furthermore, TSS values in Table 4, indicated to an increase in TSS by many treatments in the first season when 
compared with the control except glycerol in the second season which had similar effect on TSS when compared with other treatments or to the control. It was also obvious that fruit acidity was lowered by most treatments as compared with the control. However, glycerol at $1 \%$ was able to consistently reduce juice acidity. Thus, the highest juice acidity was found in the control fruits, while 1 -MCP included treatments had much lower juice acidity than the control. On the other hand, the TSS to acidity ratio was greater in all treatments when compared with the control in both seasons, while 1 - MCP treated-fruits had similar
TSS / acidity ratio except 1 - MCP treated-fruits alone in the first season that was superior to the other two treatments that were preceded by $1-\mathrm{MCP}$ then followed by $\mathrm{CaCl}_{2}$ or glycerol plus $\mathrm{CaCl}_{2}$.

With regard to the response of ascorbic acid content in the juice of "Zaghloul" dates, it was found at harvest that in most cases, there was a reduction in vitamin $\mathrm{C}$ when compared with the control. However, the application of $\mathrm{CaCl}_{2}$ plus glycerol caused a significant increase in vitamin $\mathrm{C}$ in both seasons, while this later treatment had significantly lower vitamin $\mathrm{C}$ when followed the application of 1 - MCP.

Table 4. Effect of preharvest treatments with safe chemicals on some chemical characteristics of "Zaghloul" date palm fruits during 2015 and 2016.

\begin{tabular}{|c|c|c|c|c|c|c|c|c|c|c|c|c|c|c|}
\hline \multirow[t]{2}{*}{ Characteristics } & \multicolumn{2}{|c|}{$\begin{array}{c}\text { Electrolyte } \\
\text { conductivity } \\
(\%)\end{array}$} & \multicolumn{2}{|c|}{$\begin{array}{c}\text { Anthocyanin } \\
\text { content } \\
\text { ( mgm / L) }\end{array}$} & \multicolumn{2}{|c|}{$\begin{array}{c}\text { Total } \\
\text { sugars } \\
(\%)\end{array}$} & \multicolumn{2}{|c|}{$\begin{array}{l}\text { TSS } \\
(\%)\end{array}$} & \multicolumn{2}{|c|}{$\begin{array}{l}\text { Acidity content } \\
\text { (gm/100ml } \\
\text { juice) }\end{array}$} & \multicolumn{2}{|c|}{$\begin{array}{l}\text { TSS: } \\
\text { Acidity } \\
\text { ratio }\end{array}$} & \multicolumn{2}{|c|}{$\begin{array}{c}\text { Ascorbic acid } \\
\text { content } \\
\text { (mg/100ml juice) }\end{array}$} \\
\hline & 2015 & 2016 & 2015 & 2016 & 2015 & 2016 & 2015 & 2016 & 2015 & 2016 & 2015 & 2016 & 2015 & 2016 \\
\hline Control & $34.27 \mathrm{a}^{*}$ & $37.21 \mathrm{a}$ & $23.79 \mathrm{c}$ & $28.46 \mathrm{~d}$ & $26.00 \mathrm{e}$ & $26.59 \mathrm{~d}$ & $24.60 \mathrm{~cd}$ & $25.60 \mathrm{~b}$ & $0.60 \mathrm{a}$ & $0.63 \mathrm{a}$ & $41.18 \mathrm{~d}$ & $40.69 \mathrm{c}$ & $13.19 \mathrm{~b}$ & $14.36 \mathrm{~b}$ \\
\hline MCP (50ppm) & $9.50 \mathrm{e}$ & $11.46 \mathrm{e}$ & $40.23 b$ & $44.28 \mathrm{bc}$ & $32.05 \mathrm{c}$ & $33.12 \mathrm{~b}$ & $25.80 \mathrm{~b}$ & $25.60 \mathrm{~b}$ & $0.44 \mathrm{~d}$ & $0.50 \mathrm{~cd}$ & $58.59 \mathrm{a}$ & $51.77 \mathrm{~b}$ & $b c$ & $12.42 \mathrm{c}$ \\
\hline $\mathrm{aCl}_{2}(2 \%)$ & $21.00 \mathrm{c}$ & $23.53 \mathrm{c}$ & $39.54 \mathrm{~b}$ & $43.07 \mathrm{c}$ & $34.05 \mathrm{~b}$ & $35.00 \mathrm{a}$ & $27.60 \mathrm{a}$ & $26.05 \mathrm{~b}$ & $0.52 b c$ & $0.44 \mathrm{~d}$ & $53.02 \mathrm{~b}$ & $59.50 \mathrm{a}$ & 10 & $12.03 \mathrm{~cd}$ \\
\hline eralo & $25.19 b$ & $27.91 \mathrm{~b}$ & $42.93 \mathrm{a}$ & $46.02 \mathrm{ab}$ & $35.91 \mathrm{a}$ & $36.71 \mathrm{a}$ & $26.00 \mathrm{~b}$ & $28.25 \mathrm{a}$ & $0.55 \mathrm{ab}$ & $0.59 \mathrm{ab}$ & $47.38 \mathrm{c}$ & $48.28 \mathrm{~b}$ & $11.64 \mathrm{~cd}$ & $9.70 \mathrm{e}$ \\
\hline [CP follow & $7.29 \mathrm{f}$ & $8.43 \mathrm{f}$ & $45.37 \mathrm{a}$ & $46.91 \mathrm{a}$ & $31.22 \mathrm{~cd}$ & $32.49 \mathrm{bc}$ & $25.60 \mathrm{bc}$ & $25.40 \mathrm{~b}$ & $0.50 \mathrm{bc}$ & $0.54 \mathrm{bc}$ & $51.11 \mathrm{bc}$ & $47.50 \mathrm{bc}$ & $13.19 \mathrm{~b}$ & $11.25 \mathrm{~d}$ \\
\hline $\begin{array}{l}\mathrm{MCP} \text { followed by } \\
\mathrm{CaCl}_{2} \text { plus glycerol }\end{array}$ & g & $\mathrm{g}$ & b & 43 & 2 & c & $24.00 \mathrm{~d}$ & $25.25 \mathrm{~b}$ & $\mathrm{c}$ & 0 & 4 & $\mathrm{c}$ & 10 & 9. \\
\hline $\mathrm{CaCl}_{2}$ plus glycerol & $13.65 \mathrm{~d}$ & $15.67 \mathrm{~d}$ & $37.99 \mathrm{~b}$ & $43.71 \mathrm{c}$ & $30.59 \mathrm{cc}$ & $32.00 \mathrm{bc}$ & $24.60 c$ & 25.90 & $0.47 \mathrm{cc}$ & $0.58 \mathrm{ab}$ & 52.731 & $45.47 \mathrm{bc}$ & $14.74 \mathrm{a}$ & $15.52 \mathrm{a}$ \\
\hline
\end{tabular}

\section{4- Some Mineral Content}

Due to the inclusion of calcium in some treatments, it was important to determine some relevant minerals along with calcium such as magnesium and potassium in the fruit at harvest, since they affect the integrity of the plasma membrane and the structure of the cell wall of fruit cells. The data in Table 5 provided evidence that there was a significant increase in $\mathrm{Ca}^{++}$content in the fruit tissue due to $\mathrm{CaCl}_{2}$ spray. That was the trend with the other applications that included $\mathrm{CaCl}_{2}$ such as $\mathrm{CaCl}_{2}$ plus glycerol, $\mathrm{MCP}$ when followed with either $\mathrm{CaCl}_{2}$ plus glycerol or when followed by $\mathrm{CaCl}_{2}$ alone. Moreover, $\mathrm{Mg}^{++}$content in the control fruits was greater than all other treatments in a consistent manner in both seasons.

With regard to potassium, it was found that the control fruits had lower $\mathrm{K}^{++}$content than other treatments. The potassium content affects the integrity of plasma membrane, which might further explain the greater leakage of electrolyte in the control as compared with all other used treatments. Thus, more the leakage, lower the content of potassium.

Table 5. Effect of preharvest treatments with safe chemicals on some mineral contents of "Zaghloul" date palm fruits during 2015 and 2016.

\begin{tabular}{lcccccc}
\hline \multirow{2}{*}{ Treatments } & Content & \multicolumn{2}{c}{ Ca content (\%) } & \multicolumn{2}{c}{ Mg content (\%) } & \multicolumn{2}{c}{ K content (\%) } \\
\cline { 2 - 7 } & $\mathbf{2 0 1 5}$ & $\mathbf{2 0 1 6}$ & $\mathbf{2 0 1 5}$ & $\mathbf{2 0 1 6}$ & $\mathbf{2 0 1 5}$ & $\mathbf{2 0 1 6}$ \\
\hline Control & $0.50 \mathrm{c}^{*}$ & $0.60 \mathrm{~d}$ & $0.17 \mathrm{a}$ & $0.19 \mathrm{a}$ & $1.04 \mathrm{e}$ & $1.44 \mathrm{e}$ \\
$\mathrm{MCP}(50 \mathrm{ppm})$ & $0.50 \mathrm{c}$ & $0.60 \mathrm{~d}$ & $0.11 \mathrm{~d}$ & $0.13 \mathrm{~d}$ & $2.07 \mathrm{~b}$ & $2.30 \mathrm{~b}$ \\
$\mathrm{CaCl}_{2}(2 \%)$ & $0.60 \mathrm{~b}$ & $0.72 \mathrm{c}$ & $0.13 \mathrm{c}$ & $0.15 \mathrm{c}$ & $1.77 \mathrm{c}$ & $1.95 \mathrm{c}$ \\
$\mathrm{Glycerol}(1 \%)_{\mathrm{MCP} \text { followed by } \mathrm{CaCl}_{2}}$ & $0.50 \mathrm{c}$ & $0.71 \mathrm{c}$ & $0.11 \mathrm{~d}$ & $0.11 \mathrm{e}$ & $2.12 \mathrm{~b}$ & $2.58 \mathrm{a}$ \\
$\mathrm{MCP}$ followed by CaCl$_{2}$ plus glycerol & $0.61 \mathrm{~b}$ & $0.80 \mathrm{~b}$ & $0.10 \mathrm{e}$ & $0.11 \mathrm{e}$ & $2.29 \mathrm{a}$ & $2.67 \mathrm{a}$ \\
$\mathrm{CaCl}_{2}$ plus glycerol & $0.60 \mathrm{~b}$ & $0.90 \mathrm{a}$ & $0.13 \mathrm{c}$ & $0.16 \mathrm{~b}$ & $1.65 \mathrm{~d}$ & $1.88 \mathrm{~cd}$ \\
& $0.70 \mathrm{a}$ & $0.91 \mathrm{a}$ & $0.14 \mathrm{~b}$ & $0.15 \mathrm{c}$ & $1.61 \mathrm{~d}$ & $1.81 \mathrm{~d}$
\end{tabular}

$\mathrm{CaCl}_{2}$ plus glycerol $0.70 \mathrm{a} \quad 0.91$

$0.14 \mathrm{~b}-0.15 \mathrm{c}$

$1.61 \mathrm{~d}$

$1.81 \mathrm{~d}$

difference (LSD at 0.05level).

\section{DISCUSSION}

This study provided evidences for the possibility of utilizing 1 -MCP as a mean of enhancing ripening uniformity in date palm bunches. Such effect could be attributed to the mechanism of 1 -MCP as an ethylene action inhibitor (Sisler and Serek, 2003). The timing of 1 -MCP application in this study, was very critical to hold the ripening processes in bisr dates, but the dates near maturity continued to grow and progress from near the end of the kimri stage (elongation stage) to the khalal or bisr stage, which adds to the beneficial impacts of $1-\mathrm{MCP}$ on fruits such as delaying ripening, extending the shelf life (Blankenship and Dole, 2003), reducing fruit drop and even reducing albedo breakdown in oranges (Hai et al., 2010). The effects of 1 -MCP on fruits were ascribed to its binding or blocking ethylene receptors, which inhibit the action of ethylene (Shi et al., 2013). Another important influence of 1 -MCP was reported to be reducing or slowing down membrane permeability (Zhuang et al., 2007). The consequences of enhancing "Zaghloul" date palm uniformity by preharvest spray of 1 -MCP would also mean increasing the percentage of bisr fruits, while reducing the percentage of rutab fruits, which is demanded in such cultivar that is consumed and exported mainly at the bisr (khalal) stage. Previous attempts to regulate dates ripening have been focusing on spraying the whole bunch with ethephon (ethrel) to enhance coloration and ripening, since the date palm fruit was reported to be a climacteric fruit (Rhodes, 1980; McGlosson, 1985; Abbas and Ibrahim, 1996 and Farag, 1998). Thus, an additional benefit from preharvest application of $1-\mathrm{MCP}$ at the proper time is to increase the 
total fruit weight and size and even the average fruit diameter was found in this study. Moreover, the 1-MCP - treated fruit, in general, retained a high content of vitamin $\mathrm{C}$ (ascorbic acid) and retarded the decrease in pectin level (Zhuang et al., 2007). Furthermore, the reduction of electrolyte leakage in 1 MCP -treated fruits could be due to its influence on maintaining the membrane integrity, which reflects on reducing the leakage of electrolytes (Shi et al., 2013). Moreover, the increase in $\mathrm{Ca}^{++}$content found in $\mathrm{Ca}$ - treated tissues could be attributed to its ability to compete with $\mathrm{Mg}$ ions at the plasma membrane binding sites. However, $\mathrm{Mg}^{+}$ level at harvest was still in the normal range (Salisburry and Ross, 1985) and that is very important for the tree to be able to synthesize and export carbohydrates from the leaves to various sinks such as fruits, buds, and roots.

\section{REFERENCES}

Abbas, M.F. and Ibrahim, M. A. (1996). The role of ethylene in the regulation of fruit ripening in the Hillawi date palm (Phoenix dactylifera L.). J. Sci. Food Agric., 72: 306- 308.

Blankenship, S. M. and Dole, J.M. (2003). 1Methylcyclopropene: a Review. Postharvest Biol. Tech., 28: 1-25.

Egan, H., Kird,R. S. and Sawyer,R. (1987). Pearson's Chemical Analysis of Foods. Eighth Edition. Longman Scientific and Technical Essex $\mathrm{CM}_{20} .2$ TE, England.

Farag, K. M. (1998). Development to the rutab stage without accompanied fruit softening of "Zaghloul" dates by some postharvest treatments. Proc. of the first Internatioal Conference on Date Palm. Al- Ain, UAE, PP 417- 426.

Farag, K. M. (2010). Enviromental stress physiology of the plant. In Arabic. Frist edt. Pp. 296.

Farag, K. M. (2016). Date palm, A Wealth of Healthy Food. Encyclopedia of Food and Health (FOHE). Chapter, 00215. Elsever, MRW Production Department at: MRW-FOHE@ ebevier. com.

Farag, K. M. and Kassem, H. A. (1998). Accelerating and intensifying color formation of "Zaghloul" date palm fruit using modified ethephon formations. Proceedings of the First International Meeting on Date Palm. United Arab Emirates Univ., Al- Ain, UAE. 62-71. Pp.643.
Fuleki, T. and Francis, F. J. (1968). Quantitative methods for anthocyanins. 1- Extraction and determination of total anthocyanin in cranberries. Journal of Food Science, 33:72-77.

Hai, V. T., Huong, P. T., Hegele, M. and Wunsche, J. N. (2010). The inhibition of mango (MangiferaindicaL.) fruit ripening by 1- methylcyclopropene. The International Symposium on sustainable Land Use and Rural Development in Mountainous Regions of Southeast Asia. Hanoi, 21- 23 July.

Jackson, M. 1. (1967). Soil Chemical Analysis Prentice, Hall of India Private Limited, New Delhi.

Mc Glasson, W. B. (1985). Ethylene and fruit ripening. HortSci., 20: 51- 54.

Rhodes, M.J.C. (1980). Respiration and senescence of plant organs. In: The Biochemistry of Plants. (vol. 2). Stumbf P. K. and Conn E. E. Acadmic Press, London, UK, pp 419- 462.

Salisburry, F. B. and Ross, C. W. (1985). Plant Physiology. Third edition. Wadsworth Publishing Company. California, USA, pp. 540.

SAS (1996). The Statistical Analysis System for Windows, Release 6.11. SAS Institute Inc., Cary, NC, USA.

Shi, Tang, Zhigiang Li, Zhen Zhang, Chunchun Zhang and ZhiliongGao (2013). Effect of 1methylcyclopropene (1-MCP) treatment on antioxidant enzymes of postharvest Japanese apricot. African Journal of Biotechnology, 12 (7): 689- 694.

Sisler, E. C. and Serek, M. (2003). Compounds interacting with the ethylene receptor in plants. Plant Biol., 5: 473- 480.

Zaid, A. and DeWet, P. F. (1999). Origin, geographical distribution and nutritional values of date palm. In: Date Palm Cultivation. Eds.Zind, A., and AriasJimenez, E. J. Vol- 156. Pp. 29-44. FAO Plant Production and Protection, Rome, Italy.

Zhuang, Y., Guo, C., Wu. B., Rao, J. and Mu, G. (2007). Effect of 1- MCP on physiological changes of persimmon fruits during storage period. J. Northwest Sci- Tech. Univ. of A \& F. 35: 91- 96.

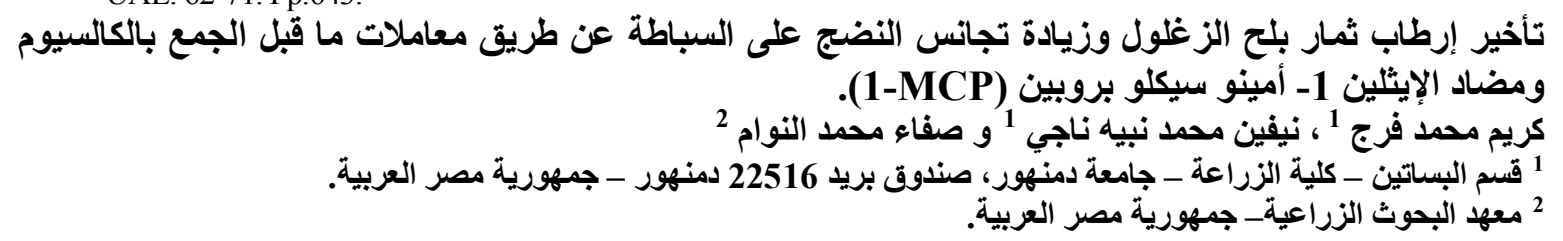

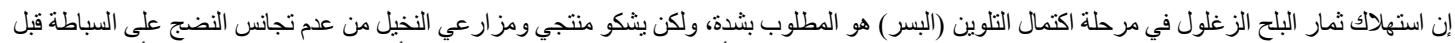

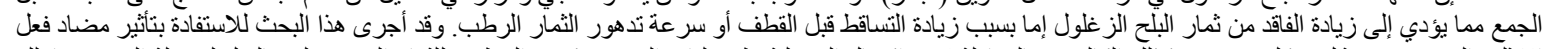

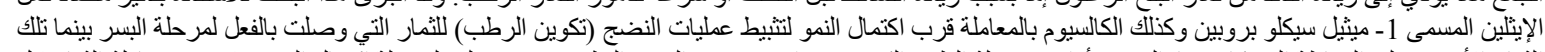

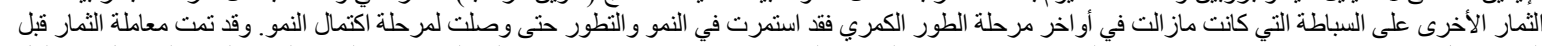

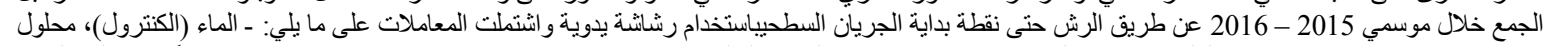

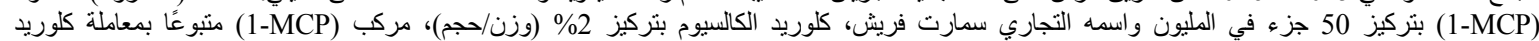

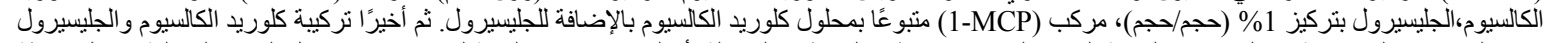

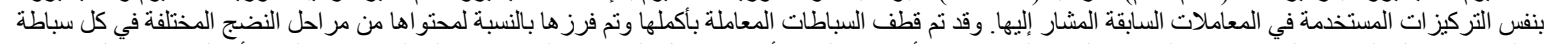

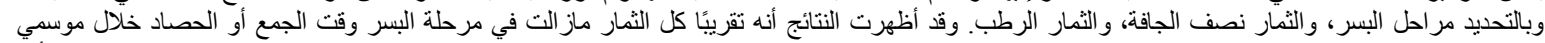

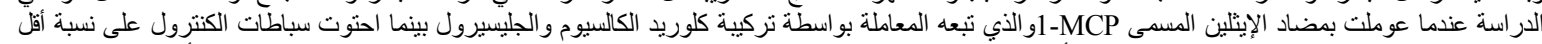

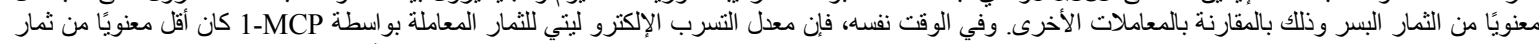

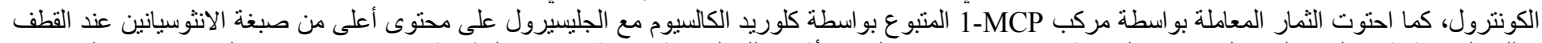

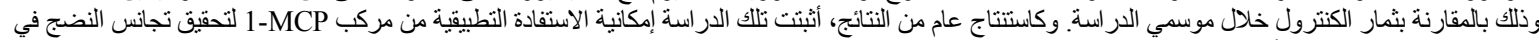
سباطة البلح الزغلول وكنلك تأخير وصول ألثمار لمرحلة الإرطاب (النضج) و إطالة مرحلة البسر. 